\title{
WORD OF MOUTH SEBAGAI EFEK RESPON POSITIF DARI KEPUASAN KONSUMEN DAN DAMPAKNYA PADA PEMBELIAN KEMBALI: STUDI KASUS MAHASISWA SEBAGAI KONSUMEN YOGHURT ACTIVIA
}

\author{
Enggal Sriwardiningsih \\ Jurusan Manajemen, Fakultas Ekonomi dan Bisnis, Bina Nusantara University \\ Jln. K.H. Syahdan No. 9, Kemanggisan, Palmerah, Jakarta Barat 11480
}

\begin{abstract}
This research want to know word of mouth as respon positive effect from consumen satisfaction and impact to repurchase. Methodology used provement of statistical test, liket scala, and a path analysis. The data came from primer sources by cross section with quesioner amount one hundred participan. Result of this riset significanly word of mouth as efek respon positif from consumen satisfaction and impact to repurchase, but interesting found that no signifikan relation between consumen satisfaction with repurchase, for his product may be another kind of consumer behavior work.
\end{abstract}

Keywords: word of mouth, satisfaction, purchase decision

\begin{abstract}
ABSTRAK
Tujuan penelitian ini adalah melihat word of mouth sebagai efek respon positif dari kepuasan konsumen untuk mengetahui pengaruh kepuasan pelanggan via word of mouth yang berdampak kepada keputusan pembelian. Metode yang digunakan dalam penelitian ini adalah pembuktian uji statistic, skala liket, dan analisa jalur. Data yang terpakai adalah data primer cross section dengan menggunakan kuesioner dengan jumlah partisipan sebesar 100 orang. Hasil penelitian ini adalah terdapat efek positif word of mouth sebagai respon dari kepuasan konsumen secara signifikan begitu juga terhadap dampaknya pada pembelian kembali, namun yang menarik adalah adanya tidak signifikan antara hubungan tidak langsung antara kepuasan konsumen dengan pembelian kembali produk tersebut diduga adanya factor lain yang mempengaruhi perilaku konsumen tersebut.
\end{abstract}

Kata kunci: word of mouth, kepuasan, keputusan pembelian 


\section{PENDAHULUAN}

Sejalan dengan meningkatnya perhatian masyarakat akan kesehatan saat ini, Yoghurt Activia dikonsumsi sebagai minuman kesehatan. Yoghurt dikenal masyarakat sebagai salah satu alternatif pengobatan sembelit atau konstipasi. Yoghurt sendiri adalah susu yang dibuat melalui fermentasi bakteri. Yoghurt dibuat dengan memasukkan bakteri spesifik ke dalam susu di bawah temperatur yang dikontrol dan kondisi lingkungan, terutama dalam produksi industri. Bakteri merombak gula susu alami dan melepaskan asam laktat sebagai produk sisa. Keasaman meningkat menyebabkan protein susu untuk membuatnya padat. Keasaman meningkat $(\mathrm{pH}=4-5)$ juga menghindari proliferasi bakteri patogen yang potensial.

Danone Activia mengerti bahwa berjalannya suatu bisnis tidak lepas dari pentingnya sebuah upaya untuk memasarkan produk yang ditawarkan kepada konsumen dengan berbagai kelebihan yang dapat menarik minat konsumen untuk datang dan mencoba. Promosi dari mulut ke mulut atau lebih dikenal dengan sebutan Word Of Mouth. Word of mouth adalah pembicara yang secara alami terjadi antar orang-orang, begitu efektif karena asal kepercayaan adalah datang dari orang yang tidak mendapat keuntungan dari rekomendasi mereka (Sernovitz, 2006), saluran informal dari komunikasi seperti teman dan tetangga, rekan kerja dan anggota keluarga (Collin \& Ivanovic, 2004), produk informasi yang disiarkan oleh sebagian orang ke orang lain. Karena mendapatkan kata-kata atau referensi dari orang yang dikenal, word of mouth akan cenderung lebih dapat dipercaya dan terpercaya daripada rekomendasi yang didapat dari channel formal marketing biasanya dalam Consumer Behaviour (Solomon, 2009). Kepuasan pelanggan adalah persepsi pelanggan bahwa harapannya telah terpenuhi atau terlampaui (Gerson, 2002). Kesimpulannya kepuasan pelanggan adalah konsep penting dalam pemasaran dan penelitian konsumen dan sudah menjadi pendapat umum bahwa jika konsumen merasa puas dengan suatu produk maka mereka akan cenderung terus menggunakannya dan membeli kembali di kemudian hari.

\section{Identifikasi Masalah}

Hal yang menjadi identifikasi masalah adalah: (1) bagaimana word of mouth sebagai efek respon positif dari kepuasan konsumen; (2) bagaimana word of mouth sebagai efek respon positif dari kepuasan konsumen menciptakan keputusan pembelian kembali; (3) bagaimanakah pengaruh kepuasan konsumen terhadap keputusan pembelian kembali.

\section{Konseptual Teori}

\section{Kepuasan Pelanggan}

Kepuasan adalah tingkat perasaan seseorang setelah membandingkan kinerja (hasil) yang dirasakan dengan harapannya (Supranto, 2006), dianggap sebagai pengukuran kualitatif dari output yang dikonsumsi oleh konsumen Irawan (2003) Faktor yang menentukan tingkat kepuasan pelanggan adalah kualitas produk, kualitas pelayanan, emosional, harga, kemudahan untuk mendapatkan produk atau jasa (Irawan, 2003). Pada dasarnya kepuasan dan ketidakpuasan dari pelanggan ditentukan oleh persepsi dan harapan pelanggan. Persepsi terhadap produk atau pelayanan sendiri dipengaruhi oleh pengalaman pelanggan saat mencoba produk atau menerima suatu pelayanan yang diperoleh mempunyai kualitas yang baik, maka besar kemungkinannya, pelanggan tersebut akan memberikan persepsi yang tinggi dan akhirnya membawa tingkat kepuasan yang lebih tinggi.

\section{Word of Mouth}

Word of mouth dapat membentuk kepercayaan para pelanggan (Hasan, 2010). Ada dua jenis word of mouth karena Organic Word Of Mouth (kualitas positif) dan Amplified Word Of Mouth, 
kampanye yang disengajakan (Sernovitz, 2006), dan efektif karena asal kepercayaan adalah datang dari orang yang tidak mendapat keuntungan dari rekomendasi mereka. (Sernovitz, (2006, p146). word of mouth begitu kuat karena kepercayaan yang bersifat mandiri dan penyampaian pengalaman (Silverman, 2001).

Octovate Consulting Group mengembangkan konsep WOM yang dibagi tiga tahap, yaitu: (1) talking, tahap awal di mana pemilik merek harus dapat mengidentifikasi talkers yang tepat dan menyediakan topik yang menarik dibicarakan; (2) promoting, adalah tersedianya tools untuk talkers agar dapat dibagikan atau disebarluaskan ke orang lain; (3) selling, bagaimana supaya bisa mempengaruhi orang lain untuk ikut menjual dan mempromosikan produk tersebut. Menurut Sernovitz (2006), terdapat tiga motivasi dasar yang mendorong pembicaraan word of mouth, yaitu menyukai anda dan produk anda, pembicaraan membuat mereka merasa baik, merasa terhubung dengan suatu kelompok.

Tabel 1 Sumber dari Word of Mouth

\begin{tabular}{|c|c|c|}
\hline \multicolumn{3}{|c|}{ Sumber dari Word of Mouth } \\
\hline Sumber & Fungsi & Isi (apa yang disediakan) \\
\hline Perusahaan & Informasi & Tuntutan,Keuangan \\
\hline Para ahli & Konfirmasi & Potensi terbaik dan terburuk dalam kondisi terbaik. \\
\hline Teman & Pembuktian & $\begin{array}{l}\text { Apa yang diharapkan dari dunia nyata, dalam } \\
\text { situasi yang khas. }\end{array}$ \\
\hline
\end{tabular}

Sumber: Silverman (2001)

\section{Keputusan untuk Membeli Kembali (Repurchase)}

Kotler \& Keller (2008), mendefinisikan adanya tahapan proses pengambilan keputusan membeli yaitu: (1) pengenalan masalah: proses pembelian dimulai ketika pembeli mengenali masalah atau kebutuhan. Kebutuhan tersebut dapat dicetuskan oleh rangsangan internal dan eksternal; (2) pencarian informasi: konsumen yang terangsang kebutuhannya akan terdorong untuk mencari informas yang lebih banyak; (3) evaluasi alternatif: konsumen berusaha memenuhi kebutuhan, manfaat produk, produk sebagai atribut berbeda yang digunakan untuk memuaskan kebutuhan itu; (4) evaluasi alternatif; dan (5) keputusan pembelian.

\section{Hipotesis}

Hipotesis pada penelitian ini adalah H1: Efek positif word of mouth berpengaruh secara signifikan terhadap respon dari kepuasan konsumen; H2: Efek positif word of mouth sebagai respon dari kepuasan konsumen berpengaruh secara signifikan terhadap dampak pembelian kembali; H3: kepuasan konsumen berpengaruh secara signifikan terhadap keputusan pembelian kembali.

\section{METODE PENELITIAN}

\section{Desain Penelitian}

Penelitian deskriptif meliputi pengumpulan data primer dengan survey untuk menguji hipotesis atau menjawab pertanyaan mengenai status terakhir dari subyek penelitian (Kuncoro, 2009), sumber data penelitian terdiri atas sumber data primer dan sekunder. Data primer merupakan sumber data penelitian yang diperoleh secara langsung dari sumber asli (Indriantoro \& Supomo, 2002). Cross section adalah studi yang dilakukan dengan mengambil sampel dalam satu waktuan dengan berbagai 
individu yang menjadi konsumen produk tersebut (Sekaran, 2006). Skala pengukuran pada penelitian ini adalah skala Likert (Sugiyono, 2007) di mana variabel adalah suatu atribut atau sifat atau nilai dari orang, objek atau kegiatan yang mempunyai variasi tertentu yang ditetapkan oleh peneliti untuk dipelajari dan ditarik kesimpulannya. Data yang diperoleh dari skala likert tersebut adalah berupa data interval. Dihitung berdasarkan rumus Slovin dari populasi sebesar 23.000 didapatkan sampel sebesar 100 partisipan dengan toleransi sebesar $10 \%$ (Riduwan \& Kuncoro, 2008).

Tabel 2 Variabel Operasional Penelitian

\begin{tabular}{|c|c|c|}
\hline Variabel & Sub Variabel & Indikator \\
\hline \multirow[t]{5}{*}{ Kepuasan konsumen ( $\mathrm{x}$ ) } & Kualitas produk & $\begin{array}{l}\text {-Kebersihan produk di kemasan } \\
\text {-Kecocokan rasa dengan selera konsumen }\end{array}$ \\
\hline & Kualitas pelayanan & -Pelayanan yang diberikan kepada pelanggan \\
\hline & Faktor emosional & -Kepuasan yang diperoleh dengan menggunakan \\
\hline & Harga & $\begin{array}{l}\text {-Kesesuaian harga terhadap produk yang ditawarkan } \\
\text {-Keterjangkauan harga }\end{array}$ \\
\hline & Kemudahan & -Kemudahan dalam mendapatkan produk \\
\hline \multirow[t]{3}{*}{ Word of mouth (Y) } & Talking & -merek tersebut dibicarakan oleh konsumen \\
\hline & Promoting & -merek terebut dipromosikan oleh konsumen \\
\hline & Selling & $\begin{array}{l}\text {-merek tersebut dijual / direkomendasikan oleh } \\
\text { konsumen }\end{array}$ \\
\hline \multirow[t]{5}{*}{ Keputusan Pembelian (Z) } & $\begin{array}{l}\text { Pengenalan masalah atau } \\
\text { kebutuhan }\end{array}$ & $\begin{array}{l}\text { - Kebutuhan yang disebabkan oleh rangsangan internal } \\
\text { dan eksternal }\end{array}$ \\
\hline & Pencarian informasi & - Aktif mencari informasi \\
\hline & Evaluasi alternatif & $\begin{array}{l}\text { - Konsumen dapat membentuk niat untuk membeli } \\
\text { merek yang paling disukai }\end{array}$ \\
\hline & Keputusan pembelian & $\begin{array}{l}\text { - Konsumen dapat membentuk niat untuk membeli } \\
\text { merek yang paling disukai }\end{array}$ \\
\hline & Perilaku setelah pembelian & -Kepuasan dan ketidakpuasan produk \\
\hline
\end{tabular}

\section{Metode Analisis}

\section{Profil Responden}

Berdasarkan jenis kelamin dan usia sebagai asumsi segment pasar yang dapat mewakili produk ini. Profil tersebut didapat dari penyebaran 100 kuesioner langsung kepada konsumen yang mengkonsumsi produk Activia di Universitas Bina Nusantara. Dengan persetujuan dan kesediaan konsumen untuk mengisi kuesioner tersebut, maka didapatkan data sebagai berikut:

Tabel 3 Jenis Kelamin dan usia

\begin{tabular}{lll}
\hline Jenis Kelamin & Jumlah & Presentase \\
\hline Wanita & 64 & $64 \%$ \\
\hline Pria & 36 & $36 \%$ \\
\hline Total & 100 & $100 \%$ \\
\hline Usia & Jumlah & Presentase \\
\hline$<18$ tahun & 5 & $5 \%$ \\
\hline $18-19$ tahun & 16 & $16 \%$ \\
\hline $20-21$ tahun & 58 & $58 \%$ \\
\hline$>21$ tahun & 21 & $21 \%$ \\
\hline Total & 100 & $100 \%$ \\
\hline
\end{tabular}


Dari data responden berdasarkan jenis kelamin, maka dapat diketahui bahwa jumlah pelanggan dengan jenis kelamin wanita lebih dominan yaitu sebesar 64\% sedangkan dari usia sekitar 20-21 tahun lebih dominan yaitu sebesar $58 \%$.

\section{Validitas}

Validitas menunjukkan sejauh mana instrument pengukur mampu mengukur apa yang ingin diukur (Santosa \& Ashari, 2005). Pada penyebaran kuesioner uji coba terhadap 30 sampel. Variabel X, $\mathrm{Y}$ dan $\mathrm{Z}$ diukur melalui butir-butir pertanyaan dengan menggunakan bantuan program SPSS diperoleh hasil semua butir pertanyaan valid.

\section{Realibilitas}

Realibilitas menunjukkan konsistensi dari alat ukur dalam mengukur gejala yang sama di lain kesempatan (Santosa \& Ashari, 2005). Salah satu pengukuran reliabilitas dapat dilakukan dengan cara one shot, pada program SPSS metode ini dilakukan dengan metode Cronbach Alpha dimana suatu kuesioner dikatakan reliable jika nilai cronbach alpha lebih besar dari 0,60. Uji realibilitas data dengan bantuan SPSS didapatkan untuk variabel X, Y dan Z diperoleh nilai Cronbach Alpha $=0.930>$ $0.17\left(\mathrm{r}_{\text {tabel }}\right)$ maka data terandalkan.

\section{Normalitas}

Uji ini merupakan pengujian yang paling banyak dilakukan untuk analisis statistik parametric, dimana asumsi yang harus dimiliki oleh data adalah bahwa data tersebut terdistribusi secara normal (Santosa \& Ashari, 2005). Variabel X memliki sig $=0.059(>0.05)$ maka data berdistribusi normal, sehingga variabel $\mathrm{X}$ dapat digunakan dalam analisis jalur berikutnya. Varibel Y memiliki sig $=0.200$ $(>0.05)$ maka data berdistribusi normal sehingga variabel $\mathrm{Y}$ dapat digunakan dalam analisis jalur berikutnya. Variabel Z memiliki sig $=0.194(>0.05)$ maka data berdistribusi normal, sehingga variabel $\mathrm{Z}$ dapat digunakan dalam analisis jalur berikutnya.

\section{Korelasi Pearson}

Korelasi adalah sebuah kekuatan dari hubungan linier antara dua variable, Misalnya X dan Y. Nilai dari Koefisien Korelasi Pearson tersebut berada diantara -1 sampai +1 , tidak mempedulikan apakah X dan Y itu (Riduwan \& Kuncoro, 2008).

\section{Regresi}

Regresi adalah proses memperkirakan secara sistematis tentang apa yang paling mungkin terjadi di masa yang akan datang berdasarkan informasi masa lalu dan sekarang yang dimiliki agar kesalahannya dapat diperkecil (Riduwan \& Kuncoro, 2008). Regresi juga diartikan untuk memprediksi perubahan di masa yang akan datang. Menurut Suliyanto (2005). Hubungan antar variable dalam persamaan regresi merupakan hubungan sebab akibat (causal relationship). Oleh karena itu, sebelum menggunakan persamaan regresi dalam menjelaskan hubungan antar dua variable atau lebih. Maka perlu diyakini terlebih dahulu bahwa secara teoritis variable-variabel tersebut memiliki hubungan (Suliyanto, 2005). 


\section{HASIL DAN PEMBAHASAN}

\section{Analisis Jalur}

Model Path Analisis digunakan untuk menganalisis pola hubungan antar variable dengan tujuan untuk mengetahui pengaruh langsung maupun tidak langsung seperangkat variable bebas terhadap variable terikat (Riduwan \& Kuncoro, 2008). Asumsi yang dipakai adalah: i) linier, adaptif dan bersifat normal, ii) aliran kausal ke satu arah, iii) variabel terikat (Endogen) minimal, iv) sampel Probability Sampling, v)Observed Variables, vi) tanpa kesalahan, vii) model dispesifikasikan.

\section{Pengujian Analisis Jalur (Path Analysis)}

Langkah pengujian analisis jalur ini dibagi menjadi dua, dimana pengujian dilakukan secara keseluruhan dan individu untuk 2 struktur yang dipecah juga menjadi sub-struktur 1 dan sub-struktur 2. Berikut ini merupakan perhitungan keseluruhan pengaruh kausal variabel Kepuasan pelanggan (X), terhadap Word of Mouth (Y) yang berdampak pada keputusan pembelian Konsumen (Z) setelah dilakukan trimming dapat digambarkan dalam model struktur lengkap seperti pada Gambar 1.

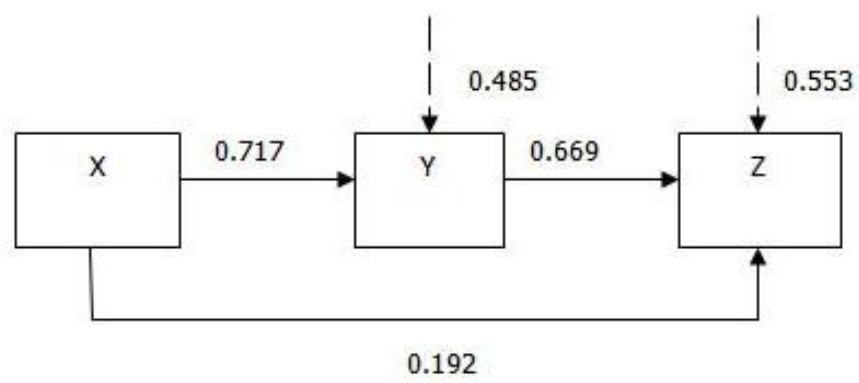

Gambar 1 Hubungan Kausal Variabel X, Y Terhadap Z Setelah Trimming

Gambar 1 menggambarkan seluruh koefisien jalur dari hubungan maka diketahui pula pengaruh langsung, pengaruh tidak langsung, serta pengaruh total dari tiap-tiap variabel yang mempengaruhi variabel tertentu. Hasilnya dirangkum dalam Tabel 4.

Tabel 4 Rangkuman Pengaruh Kepuasan Pelanggan (X); Word of Mouth (Y) secara simultan dan Signifikan terhadap Keputusan pembelian Konsumen (Z)

\begin{tabular}{llll}
\hline & \multicolumn{3}{c}{ Pengaruh kausal } \\
\cline { 2 - 4 } & Langsung & \multicolumn{2}{l}{ Tidak Langsung } \\
\cline { 2 - 4 } & & Melalui Variabel Y & Total \\
\hline X terhadap Y & 0.717 & -- & 0.717 \\
X terhadap Z & 0.192 & $0.192 \times 0.669=0.128$ & 0.32 \\
Y terhadap Z & 0.669 & -- & 0.669 \\
$\varepsilon_{1}$ & $1-0.515^{2}=0.735$ & -- & 0.735 \\
$\varepsilon_{2}$ & $1-0.447^{2}=0.800$ & -- & 0.800 \\
\hline
\end{tabular}




\section{PENUTUP}

Setelah dilakukan analisa dengan menggunakan SPSS versi 16 maka dapat diperoleh kesimpulan hasil keseluruhan pengaruh kausal variabel Kepuasan Pelanggan (X) via Word of Mouth (Y) yang berdampak pada Keputusan Pembelian Konsumen (Z) adalah sebagai berikut perhitungan analisis jalur struktural tersebut. Pengaruh kuat antara efek positif kepuasan konsumen (X) terhadap Word of Mouth $(\mathrm{Y})$ produk Activia sebesar $(0.717)^{2}$ atau $51.5 \%$ responden yang umumnya dalah wanita dan kisaran usia 20-21 karena umumnya wanita pada usia tersebut sangat peduli akan penampilan fisiknya. Hal tersebut sesuai dengan teori bahwa efek positif kepuasan konsumen dapat menciptakan Word of Mouth dengan cara lewat talking, promoting, dan selling. Dan sisanya 48.5\% nilai Word of Mouth dipengaruhi oleh variabel lainnya diluar penelitian. Pentingnya riset ini memberikan saran bagi Activia terus memperhatikan hal-hal yang dapat menimbulkan word of mouth yang positif, misalkan kualitas rasa, kualitas packaging, inovasi-inovasi varian rasa yang sesuai dengan minat konsumen di segmen tersebut. Hal ini menjawab hipotesa satu dengan baik.

Efek pisitif dari kepuasan konsumen (X), Word of Mouth (Y) memiliki kontribusi yang signifikan secara simultan terhadap Keputusan pembelian Konsumen (Z) produk Activia, bahwa secara keseluruhan menyatakan signifikan. Dengan demikian, dapat diperoleh informasi bahwa Word of Mouth berkontribusi secara simultan dan signifikan terhadap keputusan pembelian konsumen. Hal ini membutktikan bahwa hipotesa 2 terbukti dengan baik. Besarnya kontribusi Word of Mouth terhadap keputusan pembelian konsumen sebesar $0,669^{2} \times 100 \%=44.76 \%$ dan sisanya sebesar $55.24 \%$ dipengaruhi faktor-faktor lain di luar penelitian ini dengan memperkuat aktifitas selling. Pengaruh tidak langsung Kepuasan pelanggan (X) terhadap Keputusan pembelian Konsumen $(\mathrm{Z})$ melalui Word of Mouth (Y) sebesar 0.32. Dengan demikian pengaruh X a Z sebesar 0.32. Menarik sekali dalam hal ini adalah Hipotesa 3 tidak terbukti. Peneliti menduga adanya perilaku konsumen yang tidak terdeteksi oleh indicator yang di teliti dalam riset ini, atau mungkin produk ini memiliki perilaku unik mengingat produk ini bukanlah minuman biasa yang biasa dikonsumsi oleh masyarakat secara keseluruhan (bukan konsumsi pokok sehari-hari. Hal ini membuka celah untuk diteliti lebih lanjut bagi peneliti berikutnya.

\section{Saran}

Ada beberapa saran yang diusulkan untuk penelitian selanjutnya. Saran-saran yang diusulkan berdasarkan hasil penelitian ini adalah: Hipotesa 3 yaitu kepuasan konsumen berpengaruh secara signifikan terhadap keputusan pembelian kembali tidak terbukti. Peneliti menduga adanya perilaku konsumen yang tidak terdeteksi oleh indicator yang di teliti dalam riset ini, atau mungkin produk ini memiliki perilaku unik mengingat produk ini bukanlah minuman biasa yang biasa dikonsumsi oleh masyarakat secara keseluruhan (bukan konsumsi pokok sehari-hari). Hal ini membuka celah untuk diteliti lebih lanjut bagi peneliti berikutnya.

\section{DAFTAR PUSTAKA}

Collin, P. H., \& Ivanovic, A. (2004). Dictionary of marketing (3rd ed.). United States of America: Bloomsbury Publishing.

Gerson, R. F. (2002). Mengukur tingkat kepuasan panduan menciptakan pelayanan bermutu. Jakarta: PPM.

Hasan, A. (2010). Marketing dari mulut ke mulut. Yogyakarta: Media Presindo. 
Indriantoro, N., \& Supomo, B. (2002). Metodologi penelitian bisnis untuk akuntansi dan manajemen (1st ed.). Yogyakarta: BPFE.

Irawan, H. (2003). Indonesian customer satisfaction: Membedah strategi kepuasan pelanggan merek pemenang ICSA. Jakarta: Elex Media Komputindo.

Kotler, P., \& Keller, K. L. (2008). Manajemen pemasaran Jilid 1 (12th ed.). Jakarta: Indeks.

Kuncoro, M. (2009). Metode riset untuk bisnis dan ekonomi (3rd ed.). Jakarta: Erlangga.

Solomon, M. (2009). Consumer behaviour buying, having, and being (8th ed.). Prentice Hall.

Riduwan, \& Kuncoro, E. A. (2008). Cara menggunakan dan memakai analisis jalur (2nd ed.). Bandung: Alfabeta.

Santosa, P. B., \& Ashari. (2005). Analisis statistik dengan Microsoft Excel dan SPSS. Yogyakarta: ANDI.

Sekaran, U. (2006). Metodologi penelitian untuk bisnis (4th ed.). Jakarta: Salemba Empat.

Sernovitz, A. (2006). Word of mouth marketing: How smart companies get people talking. Chicago: Kaplan Publishing.

Silverman, G. (2001). The secret of word of mouth marketing: How to trigger exponential sales through runaway word of mouth. United States Of America: Amacam.

Sugiono. (2007). Statistika untuk penelitian. Bandung: Alfabeta.

Suliyanto. (2005). Analisis data dalam aplikasi pemasaran. Bogor: Ghalia Indonesia.

Supranto, J. (2006). Pengukuran tingkat kepuasan pelanggan. Jakarta: Rineka Cipta. 